\title{
LY248686, A New Inhibitor of Serotonin and Norepinephrine Uptake
}

David T. Wong, Ph.D., Frank P. Bymaster, M.S., Douglas A. Mayle, B.S., Leroy R. Reid, B.S., Joseph H. Krushinski, M.S., and David W. Robertson, Ph.D.

LY248686 is an inhibitor of serotonin (5-hydroxytryptamine; 5-HT) and norepinephrine (NE) uptake in synaptosomal preparations of hypothalamus and cerebral cortex, and 5-HT uptake in human blood platelets, with inhibitor constants near nanomolar concentrations. Upon administration to rats 1 hour before sacrifice, LY248686 caused dose-dependent and parallel decreases of 5-HT and NE uptake in hypothalamus homogenates ex vivo. LY248686 is a positive enantiomer and was slightly more potent than its negative isomer, LY248685, as an inhibitor of 5-HT uptake. Both isomers were only weak inhibitors of dopamine (DA) uptake in striatal synaptosomes. The inhibitory effects on 5-HT and NE uptake after a single administration of LY248686 followed similar time courses and simultaneously persisted for as long as 6 hours. LY248686 in vivo could effectively antagonize the p-chloroamphetamine-induced decreases of 5-HT uptake and levels of 5-HT and 5-hydroxyindoleacetic acid in cerebral cortex, and block the accumulation of ${ }^{14} \mathrm{C}-\mathrm{NE}$ in rat hearts. In food deprived rats, LY248686 suppressed food intake synergistically with 5-hydroxytryptophan, a precursor amino acid of 5-HT. Because of its lack of affinity for receptors of 5-HT, NE, DA, acetylcholine, histamine and naloxone, and its ability to inhibit 5-HT and NE uptake simultaneously, LY248686 has a favorable pharmacological profile as a potential antidepressant drug. [Neuropsychopharmacology 8:23-33, 1993]
KEY WORDS: Uptake; Inhibitor; Serotonin; Norepinephrine

The extent of inhibition of serotonin (5-hydroxytryptamine; 5-HT) and norepinephrine (NE) uptake by the tricyclic tertiary amine-containing antidepressant drugs depends on their relative degrees of metabolic $\mathrm{N}$-demethylation. Amitriptyline, an inhibitor of 5-HT and NE uptake in nerve-ending preparations (synaptosomes), is converted in vivo to nortriptyline, a potent and selective inhibitor of NE uptake, while imipramine, a selective inhibitor of 5-HT uptake, is converted to desipramine, another potent and selective inhibitor

From the Lilly Research Laboratories, Eli Lilly and Company, Indianapolis, Indiana.

Address correspondence to Dr. David T. Wong, Lilly Research Laboratories, Eli Lilly and Company, Lilly Corporate Center, Indianapolis, IN 46285.

Received September 19, 1991; revised January 15, 1992; accepted January 27, 1992. of NE uptake (Richelson 1987; Narasimhachari and Landa 1991). Blood levels of amitriptyline and imipramine and their demethylated metabolites vary widely (Muscettola et al. 1978; Corona et al. 1990; Narasimhachari and Landa, 1991). Indeed, animal studies showed that acute administration of amitriptyline and imipramine inhibited NE uptake more effectively than 5-HT uptake in vivo (Wong and Bymaster 1976; Fuller and Wong 1987). We have developed fluoxetine, a selective inhibitor of 5-HT uptake, and tomoxetine, a selective inhibitor of NE uptake, as potential antidepressant drugs (Wong et al. 1974, 1975, 1982). Fluoxetine is now available in many countries for the treatment of depression (Benfield et al. 1986; Beasley et al. 1990), while a preliminary study suggested that tomoxetine might have antidepressant activity (Chouinard et al. 1984). In this article, we report that $L Y 248686$ (a positive isomer; Fig. 1) is a potent and competitive inhibitor of $5-\mathrm{HT}$ and NE uptake, while the negative isomer (LY248685) is slightly less potent as an inhibitor of 5-HT uptake in 


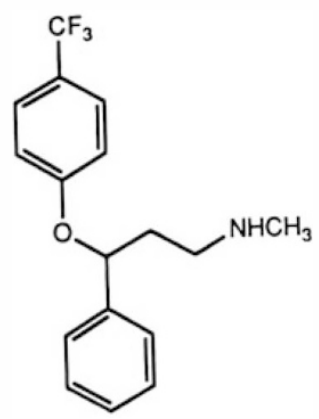

Fluoxetine
Tomoxetine
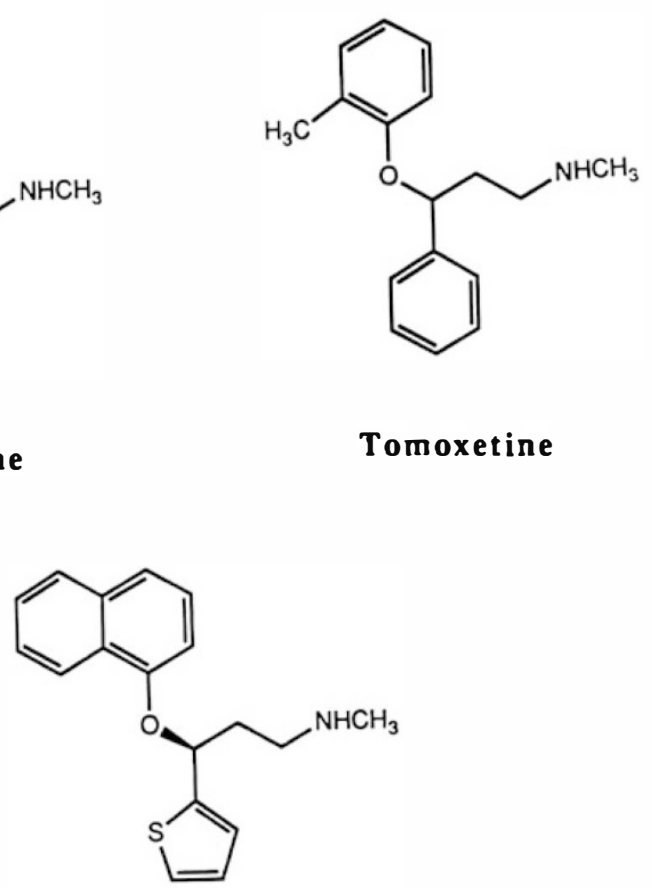

\section{Y 248686}

Figure 1. Chemical structures of fluoxetine, tomoxetine, and LY248686 [(+)-N-methyl-3-(1-naphthalenyloxy)-2-thiophenepropanamine].

vitro and in vivo. Because of its pharmacological profile, LY248686 may be a potentially useful antidepressant drug that can inhibit both 5-HT and NE uptake, leading to simultaneous increases of 5-HT and NE transmission. Moreover, because of its ability to suppress food intake in rats, LY248686 might have a low propensity to cause weight gain, a common side effect of tricyclic antidepressant drugs.

\section{MATERIALS AND METHODS}

\section{Monoamine Uptake In Vitro}

Sprague-Dawley rats in groups of 10 animals (100 to $150 \mathrm{~g}$; Harlan Industries, Cumberland, IN) were housed in a room with a 12-hour dark/light cycle (lights on at 0600 ) at $23^{\circ} \mathrm{C}$ and had free access to Purina rat chow pellets and water. Rats were killed by decapitation. Whole brains were removed and brain areas were immediately dissected. Cerebral cortex, hypothalamus, or striatum was homogenized in nine volumes of a medium containing $0.32 \mathrm{~mol} / \mathrm{L}$ sucrose and $20 \mathrm{mmol} / \mathrm{L}$ glucose. Crude synaptosomal preparations were isolated after differential centrifugation at $1,000 \mathrm{~g}$ for 10 minutes and $17,000 \mathrm{~g}$ for 28 minutes. The final pellets were suspended in the same medium and kept on ice until used within the same day.

Synaptosomal uptake of ${ }^{3} \mathrm{H}-5-\mathrm{HT},{ }^{3} \mathrm{H}-\mathrm{NE}$ or ${ }^{3} \mathrm{H}$ dopamine ( $\left.{ }^{3} \mathrm{H}-\mathrm{DA}\right)$ was determined as follows: synaptosomal preparations (equivalent to 0.5 to $1 \mathrm{mg}$ protein) were incubated at $37^{\circ} \mathrm{C}$ for 5 minutes in $1 \mathrm{ml}$ of Krebsbicarbonate medium containing $10 \mathrm{mmol} / \mathrm{L}$ glucose, 0.1 $\mathrm{mmol} / \mathrm{L}$ iproniazid, $1 \mathrm{mmol} / \mathrm{L}$ ascorbic acid, $0.17 \mathrm{~mol} / \mathrm{L}$ ethylene-diamine tetraacetic acid (EDTA), ${ }^{3} \mathrm{H}$-monoamine at a specified concentration, and compounds at 5 or more concentrations. The reaction mixture was immediately diluted with $2 \mathrm{ml} 0.9 \%$ saline and filtered, using Whatman GF/B filters, under vacuum with a cell harvester (Brandel, Gaithersburg, MD). Filters were rinsed twice with approximately $5 \mathrm{ml}$ ice-chilled $0.9 \%$ saline and were transferred to a counting vial containing $10 \mathrm{ml}$ scintillation fluid (PCS; Amersham, Arlington Heights, IL). Radioactivity was measured by a liquid scintillation spectrophotometer. Accumulation of radioactivity at $4^{\circ} \mathrm{C}$ represented the background and was subtracted from all samples.

The uptake of ${ }^{3} \mathrm{H}-5-\mathrm{HT}$ into human platelets was assessed using a modification of the published method (Horng and Wong 1976). Blood ( $40 \mathrm{ml})$ was drawn from a healthy human volunteer into a syringe containing $4 \mathrm{ml} \mathrm{3.8 \%}$ sodium citrate in normal saline, $\mathrm{pH} 7.4$. After the addition of another $4 \mathrm{ml}$ normal saline, the blood was centrifuged at $100 \mathrm{~g}$ for 15 minutes at room temperature. The resulting top layer of platelet-rich plasma was recovered, an aliquot taken for platelet concentra. tion determination, and the remainder stored on ice until use, within 2 hours. The platelet-rich plasma was then diluted to a concentration of $126 \times 10^{3}$ platelets/microliter, and a $0.1-\mathrm{ml}$ aliquot was mixed with $2 \mathrm{ml}$ Krebs-bicarbonate buffer, $\mathrm{pH}$ 7.4, containing 10 $\mathrm{mmol} / \mathrm{L}$ glucose, $0.1 \mathrm{mmol} / \mathrm{L}$ iproniazid, $1 \mathrm{mmol} / \mathrm{L}$ ascorbic acid, $0.17 \mathrm{mmol} / \mathrm{L}$ EDTA, and $21 \mu \mathrm{l}$ of each drug, respectively, resulting in a reaction medium containing $1.26 \times 10^{7}$ platelets and $50 \mathrm{nmol} / \mathrm{L}{ }^{3} \mathrm{H}-5-\mathrm{HT}$. Triplicate samples wereincubated at $37^{\circ} \mathrm{C}$ for 3 minutes; $0.1 \mathrm{ml} 20 \%$ formaldehyde was then quickly added to each tube to terminate the reaction. Platelets were harvested by filtration through Whatman $G F / B$ filters using a cell harvester. Radioactivity on the filter was measured by liquid scintillation. Radioactivity in platelets incubated at $4^{\circ} \mathrm{C}$ represents nonspecific uptake. Inhibjtor constants (Ki values) were calculated from $\mathrm{IC}_{\mathbf{s}}$ values (concentrations that inhibit $50 \%$ of ${ }^{3} \mathrm{H}$-monoamine uptake of radioligand binding) according to the method of Cheng and Prusoff (1973).

\section{Inhibition of Monoamine Uptake In Vivo}

For in vivo studies, rats (five animals per group) were fasted overnight before oral administration of drugs. Alternatively, rats (five animals per group) fed ad libi. 
tum were given drugs by the specified routes and doses. Ratswere killed by decapitation 1 hour after drug treatment or at the specified time intervals. Brains were quickly removed, dissected, and placed either in cold $0.32 \mathrm{~mol} / \mathrm{L}$ sucrose medium for uptake studies or were frozen on dry ice for determinations of monoamine and metabolite levels. In uptake studies, the hypothalamus washomogenized in $0.6 \mathrm{ml}$ medium, striatum from the right side in $1 \mathrm{ml}$ medium, and one-half cortex in $5 \mathrm{ml}$ medium; this yielded 0.5 to $1.0 \mathrm{mg}$ protein per $0.1 \mathrm{ml}$.

The uptake of ${ }^{14} \mathrm{C}-\mathrm{NE}$ in rat heart was determined by a modification of the method of Hertting et al. (1961). Drugs were administered 30 minutes before intravenous administration of $1 \mu \mathrm{Ci}{ }^{14} \mathrm{C}$-NE. After 15 minutes, the rats were killed by decapitation and the hearts were removed, opened, blotted, and frozen on dry ice. After digestion in $1 \mathrm{ml}$ heated 9:1 (vol/vol) $30 \% \mathrm{H}_{2} \mathrm{O}_{2} / 70 \%$ perchloric acid, $10 \mathrm{ml}$ scintillation fluid was added and radioactivity was determined by liquid scintillation spectrometery.

\section{HPLC Procedure to Measure Metabolites}

For measurement of monoamines and metabolites, brain tissues were homogenized in 5 to 10 volumes of $0.1 \mathrm{~N}$ trichloroacetic acid containing internal standard (5-hydroxyindolecarboxylic acid) and then centrifuged at $10,000 \mathrm{~g}$ for 10 minutes. The monoamines and metabolites in $20 \mu \mathrm{l}$ supernatant were separated by HPLC and measured by electrochemical detection. The analytical column was a $150 \times 4.6-\mathrm{mm} \mathrm{C} 18-5$, micron reverse-phase column (Alltech, Deerfield, IL) heated to $40^{\circ} \mathrm{C}$. The mobile phase, containing $0.1 \mathrm{~mol} / \mathrm{L}$ monochloroacetic acid, $\mathrm{pH}$ 2.6, $0.5 \mathrm{mmol} / \mathrm{L}$ EDTA, 7.5\% acetonitrile, and $150 \mathrm{mg} / \mathrm{l}$ of $\mathrm{Na}$ octylsulfonate, was pumped at $1 \mathrm{ml} / \mathrm{min}$. Internal standards-homovanillic acid, 5-HIAA (5-hydroxyindole acetic acid), and 5-HT, respectively-were eluated and determined amperometrically using a glassy carbon electrode at 0.83 volts $\mathrm{Ag} / \mathrm{AgCl}$. Peak heights were measured and corrected using the internal standard, and quantities were calculated by comparing to a standard curve.

\section{Radiolabeled Ligand Binding in Brain Membrane Preparations}

The synaptosomal preparation of rat cerebral cortex or bovine striatum was suspended by homogenizing in 50 volumes of cold reaction medium $(50 \mathrm{mmol} / \mathrm{L}$ Tris, $150 \mathrm{mmol} / \mathrm{L} \mathrm{NaCl}, 50 \mathrm{mmol} / \mathrm{L} \mathrm{KCl}, \mathrm{pH} \mathrm{7.4)}$ and centrifuging at $50,000 \mathrm{~g}$ for 10 minutes. The process was repeated two times with a 10 -minuteincubation at $37^{\circ} \mathrm{C}$ between the second and third washes. The resulting pellet was stored at $-70^{\circ} \mathrm{C}$ until use.

Binding of ${ }^{3} \mathrm{H}$-paroxetine to 5-HT uptake sites was carried out in $2 \mathrm{ml}$ reaction medium containing the appropriate drug concentration, $0.1 \mathrm{nmol} / \mathrm{L}{ }^{3} \mathrm{H}$-paroxetine, and the cerebral cortical membrane $(50 \mu \mathrm{g}$ protein/tube) (Marcusson et al. 1988), while ${ }^{3} \mathrm{H}$-tomoxetine at $0.2 \mathrm{nmol} / \mathrm{L}$ was used to label $\mathrm{NE}$ uptake sites using a higher concentration of $300 \mathrm{mmol} / \mathrm{L} \mathrm{NaCl}$, as previously described (Wong et al. 1991). Samples were incubated at $37^{\circ} \mathrm{C}$ for 30 minutes; those containing $1 \mu \mathrm{mol} / \mathrm{L}$ fluoxetine or desipramine were used to determine nonspecific binding of ${ }^{3} \mathrm{H}$-paroxetine and ${ }^{3} \mathrm{H}$-tomoxetine, respectively. After incubation, the tubes were filtered through Whatman GF/B filters, which were soaked in $0.05 \%$ polyethylenimine for 1 hour before use, using a cell harvester by adding about $4 \mathrm{ml}$ cold Tris buffer ( $\mathrm{pH} \mathrm{7.4),} \mathrm{aspirating,} \mathrm{and} \mathrm{rinsing}$ the tubes three additional times. Filters were then placed in scintillation vials containing $10 \mathrm{ml}$ scintillation fluid, and the radioactivity was measured by liquid scintillation spectrophotometry.

Radioligand binding to various receptors of neurotransmitters was measured by the established procedures as listed in Table 1.

\section{Food Intake Studies}

Male Sprague-Dawley rats ( $250 \mathrm{~g}$; three or six animals per group) were meal-fed Purina rat chow and allowed water ad libitum for at least 3 days in our laboratory before being used in the study. Rats were then fasted for 42 hours. Inhibitors of monoamine uptake were administered at the specified doses 30 minutes before feeding. Food intake was recorded by weighing the pellets and spillage at the beginning and end of the indicated periods of time.

LY248686, (+)-N-methyl-3-(1-naphthalenyloxy)-2thiophenepropanamine, ethandioate, its negative isomer (LY248685), and its racemic mixture (LY227942) were synthesized in the Lilly Research Laboratories (Indianapolis, IN). 5-HT [1,2- $\left.{ }^{3} \mathrm{H}(\mathrm{N})\right](28.7 \mathrm{Ci} / \mathrm{mmol}), 1-\mathrm{NE}$ $\left[8-{ }^{14} \mathrm{C}\right](57 \mathrm{mCi} / \mathrm{mmol}), \mathrm{DA}\left[7-{ }^{3} \mathrm{H}(\mathrm{N})\right](26.8 \mathrm{Ci} / \mathrm{mmol})$, phenyl-6- ${ }^{3} \mathrm{H}$-paroxetine $(25 \mathrm{Ci} / \mathrm{mmol}), \mathrm{N}$-methyl- ${ }^{3} \mathrm{H}-$ tomoxetine $(80.3 \mathrm{Ci} / \mathrm{mmol})$, propyl-2,3-ring $1,2,3-{ }^{3} \mathrm{H}$ 8-OH-DPAT $(169.9 \mathrm{Ci} / \mathrm{mmol})$, ethylene- ${ }^{3} \mathrm{H}$-ketanserin (64.9 Ci/mmol), benzene-ring- ${ }^{3} \mathrm{H}$-spiperone $(23.3$ $\mathrm{Ci} / \mathrm{mmol})$, pyridinyl-5- ${ }^{3} \mathrm{H}$-pyrilamine $(27.3 \mathrm{Ci} / \mathrm{mmol})$, ( \pm )benzilic-4'- ${ }^{3} \mathrm{H}(\mathrm{N})$-quinuclidinyl benzilate, QNB (33.1 Ci/mmol), 2-phenoxy-3-3 $\mathrm{H}(\mathrm{N})-\mathrm{WB} 4101$ (24 Ci/ $\mathrm{mmol}),{ }^{3}{ }^{3} \mathrm{H}$-clonidine $(22.2 \mathrm{Ci} / \mathrm{mmol})$, and ${ }^{3} \mathrm{H}$-naloxone $(38 \mathrm{Ci} / \mathrm{mmol})$, were purchased from New England Nuclear (Boston, MA). N-6[methyl- $\left.{ }^{3} \mathrm{H}\right]$ mesulergine was purchased from Amersham (Arlington Heights, IL).

Statistical analysis was conducted by the use of Student's $t$ test to compare means of control and drugtreated samples. Probability less than 0.05 was regarded as significant. 
Table 1. Conditions of $\left[{ }^{3} \mathrm{H}\right]$ Ligand Binding Studies

\begin{tabular}{|c|c|c|c|c|}
\hline Receptor & {$\left[{ }^{3} \mathrm{H}\right]$ Ligand } & Tissue & $\begin{array}{c}\text { Determinant of } \\
\text { Nonspecific Binding }\end{array}$ & References \\
\hline $5-\mathrm{HT}_{1 \mathrm{~A}}$ & 8-OH-DPAT & Cerebral cortex (R) & $10^{-5} \mathrm{M} 5-\mathrm{HT}$ & Gozlan et al. 1983 \\
\hline $5-\mathrm{HT}_{1 \mathrm{~B}}$ & 5-HT & Cerebral cortex (R) & $10^{-5} \mathrm{M} 5-\mathrm{HT}$ & Doods et al. 1985 \\
\hline $5-\mathrm{HT}_{1 \mathrm{C}}$ & Mesulergine & Choroid plexus (B) & $10^{-5}$ M 5-HT & Hoyer et al. 1985 \\
\hline $5-\mathrm{HT}_{1 \mathrm{D}}$ & $5-\mathrm{HT}$ & Striatum (B) & $10^{-5} \mathrm{M}$ 5-HT & Heuring and Peroutka 1987 \\
\hline $5-\mathrm{HT}_{2}$ & Ketanserin & Cerebral cortex (R) & $10^{-5} \mathrm{M}$ spiperone & Leysen et al. 1982 \\
\hline $\mathrm{D}_{2}$ & Spiperone & Striatum (B) & $3 \times 10^{-6} \mathbf{M}(+)$-butaclamol & Wong et al. 1983 \\
\hline Opiate & Naloxone & Striatum (R) & $10^{-6} \mathrm{M}$ naltrexone & Wong et al. 1983 \\
\hline Ach-M & QNB & Cerebral cortex (R) & $10^{-6} \mathrm{M}$ atropine & Wong et al. 1983 \\
\hline $\mathrm{H}_{1}$ & Pyrilamine & Cerebral cortex (R) & $10^{-6} \mathrm{M}$ pyrilamine & Wong et al. 1983 \\
\hline$\alpha_{1}$ & WB4101 & Cerebral cortex (B) & $10^{-6} \mathrm{M}$ prazocin & Wong et al. 1983 \\
\hline$\alpha_{2}$ & Clonidine & Cerebral cortex (R) & $10^{-5} \mathrm{M}$ norepinephrine & Wong et al. 1983 \\
\hline
\end{tabular}

$\mathrm{R}$, Rat; B, bovine.

\section{RESULTS}

\section{In Vitro Inhibition of Uptake}

LY248686 inhibited 5-HT uptake in synaptosomal preparations of hypothalamus (Fig. 2A) most potently, with an IC 50 of $2.6 \pm 0.4 \mathrm{nmol} / \mathrm{L}$, followed by the nega-

\section{(A) Inhibition of Serotonin Uptake}

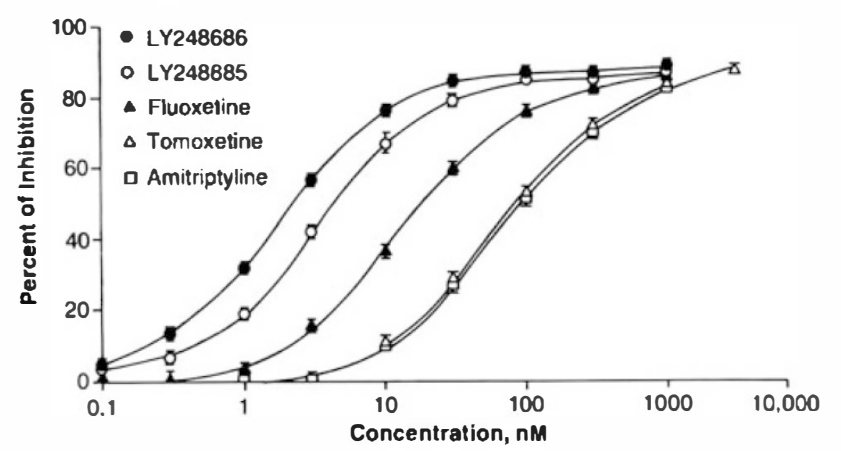

(B) Inhibition of Norepinephrine Uptake

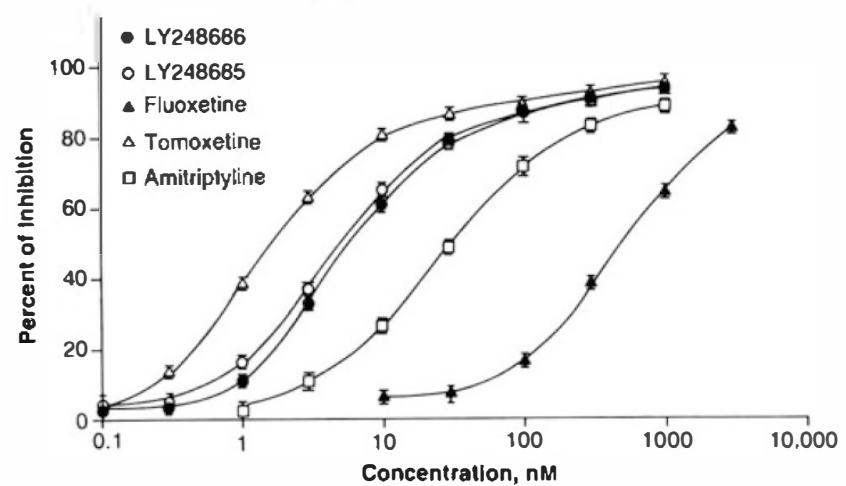

Figure 2. Inhibition of 5-HT and NE uptake in synaptosomal preparation isolated from rat hypothalamus. Synaptosomes (equivalent to $1 \mathrm{mg}$ protein) were incubated in triplicate at $37^{\circ} \mathrm{C}$ for 3 minutes in Krebs bicarbonate buffer ( $\mathrm{pH} 7.4$ ) containing $10 \mathrm{mmol} / \mathrm{L}$ glucose, $0.1 \mathrm{mmol} / \mathrm{L}$ iproniazid, $0.2 \mathrm{mg} / \mathrm{ml}$ ascorbic acid, $0.2 \mathrm{mmol} / \mathrm{L}$ EDTA, and various concentrations of LY248686 (O), LY248685 (O), fluoxetine $(\Delta)$, tomoxetine $(\Delta)$ or amitriptyline $(\square)$ and $0.05 \mu \mathrm{mol} / \mathrm{L}{ }^{3} \mathrm{H}-5-\mathrm{HT}(A)$ or ${ }^{3} \mathrm{H}-\mathrm{NE}(B)$. tive isomer (LY248685) and fluoxetine, with $\mathrm{IC}_{50}$ values of $5.3 \pm 0.9$ and $22.4 \pm 3.6 \mathrm{nmol} / \mathrm{L}$, respectively. Tomoxetine and amitriptyline were weaker, with $\mathrm{IC}_{50}$ values of $99.3 \pm 16.3$ and $106.2 \pm 16.6 \mathrm{nmol} / \mathrm{L}$, respectively. Both LY248686 and its negative isomer inhibited NE uptake in hypothalamic synaptosomes (Fig. 2B) with about equal potencies, as indicated by their $\mathrm{IC}_{50}$ values of 7.0 \pm 0.8 and $6.0 \pm 0.7 \mathrm{nmol} / \mathrm{L}$, respectively. As reported previously (Wong et al. 1982), tomoxetine (LY139603) potently inhibited NE uptake effectively, with an $\mathrm{IC}_{50}$ of $1.9 \pm 0.2 \mathrm{nmol} / \mathrm{L}$, while amitriptyline was moderately potent, with an $\mathrm{IC}_{50}$ of $34.8 \pm 4.0 \mathrm{nmol} / \mathrm{L}$, and fluoxetine was least potent, with an $\mathrm{IC}_{50}$ of $517.5 \pm$ $56.9 \mathrm{nmol} / \mathrm{L}$.

The uptake of 5-HT in cortical synaptosomes was inhibited by the two optical isomers and the dextrorotatory isomer was slightly more potent, as indicated by their inhibitor constants ( $\mathrm{Ki}$ values; Table 2). Both isomers were about equipotent as inhibitors of NE uptake in cortical synaptosomes (Table 2). The dextrorotatory and levorotatory isomers inhibited DA uptake in striatal synaptosomes at concentrations 80 and 75 times higher than the $\mathrm{Ki}$ concentrations needed to inhibit 5-HT uptake, and 24 and 41 times higher than the Ki concentrations needed to inhibit NE uptake.

Uptake of 5-HT in human platelets was potently inhibited by both isomers (Table 2). Again, LY248686 was slightly more potent than LY248685, as indicated by their Ki values.

LY248686 inhibited the sodium-dependent binding of ${ }^{3} \mathrm{H}$-paroxetine (Marcusson et al. 1988) and ${ }^{3} \mathrm{H}$ tomoxetine (Wong et al. 1991) to uptake carriers of 5-HT and $\mathrm{NE}$, with $\mathrm{Ki}$ values of $0.53 \pm 0.10$ and $2.1 \pm 1.1$ $\mathrm{nmol} / \mathrm{L}$, respectively (Table 2). The negative isomer, LY248685, was slightly less potent than LY248686 in blocking ${ }^{3} \mathrm{H}$-paroxetine binding.

\section{In Vivo Inhibition of Uptake}

In hypothalamic homogenates of rats treated with LY248686 oxalate at 5, 10, and $20 \mathrm{mg} / \mathrm{kg} \mathrm{PO}, 5-\mathrm{HT}$ and 
Table 2. Inhibition of Monoamine Uptake and Radioligand Binding to Uptake Carriers by LY248685 in Vitro

\begin{tabular}{|c|c|c|}
\hline \multirow[b]{2}{*}{ Measurement } & \multicolumn{2}{|c|}{ Ki (nanomoles/liter) } \\
\hline & LY248686 & LY248685 \\
\hline $\begin{array}{l}\text { Synaptosomal uptake } \\
{ }^{3} \mathrm{H}-5-\mathrm{HT} \\
{ }^{3} \mathrm{H}-\mathrm{NE} \\
{ }^{3} \mathrm{H}-\mathrm{DA} \\
{ }^{3} \mathrm{H}-\text { Paroxetine binding } \\
{ }^{3} \mathrm{H}-\mathrm{Tomoxe} \text { ome binding } \\
{ }^{3} \mathrm{H}-5-\mathrm{HT} \text { uptake in human platelets }\end{array}$ & $\begin{aligned} 4.6 & \pm 1.1 \\
15.6 & \pm 2.9 \\
369.2 & \pm 38.1 \\
0.53 & \pm 0.10 \\
2.1 & \pm 1.1 \\
0.20 & \pm 0.04\end{aligned}$ & $\begin{aligned} 8.8 & \pm 2.5 \\
15.9 & \pm 4.2 \\
659.3 & \pm 113.1 \\
0.72 & \pm 0.16 \\
1.7 & \pm 0.6 \\
0.35 & \pm 0.06\end{aligned}$ \\
\hline \multicolumn{3}{|c|}{$\begin{array}{l}\text { Synaptosomal preparations (equivalent to } 1 \mathrm{mg} \text { protein) isolated from cerebral cortex were incubated } \\
\text { in triplicate samples at } 37^{\circ} \mathrm{C} \text { for } 3 \text { minutes in } \mathrm{Krebs} \text { bicarbonate (saturated with } 95 \% \mathrm{O}_{2} \text { and } 5 \% \mathrm{CO}_{2} \text { ), } \\
\text { pH 7.4, containing } 10 \mathrm{mmol} / \mathrm{L} \text { glucose, } 0.1 \mathrm{nmol} / \mathrm{L} \text { iproniazid, } 0.2 \mathrm{mg} / \mathrm{ml} \text { ascorbic acid, } 0.2 \mathrm{mmol} / \mathrm{L} \\
\text { EDTA, } 0.05 \mu \mathrm{mol} / \mathrm{L}\left[{ }^{3} \mathrm{H}\right]-5-\mathrm{HT} \text { or }\left[{ }^{3} \mathrm{H}\right]-\mathrm{NE} \text { and an uptake inhibitor at five or more concentrations. Up- } \\
\text { take of }\left[{ }^{3} \mathrm{H}\right]-\mathrm{DA} \text { was conducted in striatal preparations. }{ }^{3} \mathrm{H} \text {-Paroxetine and }{ }^{3} \mathrm{H} \text {-tomoxetine binding } \\
\text { studies in cortical membranes and }{ }^{3} \mathrm{H}-5-\mathrm{HT} \text { uptake in human blood platelets were conducted as } \\
\text { described in Materials and Methods. Values (mean } \pm \mathrm{SE} \text { ) were obtained from three or more separate } \\
\text { determinations. The inhibitor constants (Ki values) were calculated from IC } \mathrm{C}_{50} \text { values according to the } \\
\text { method of Cheng and Prusoff (1973). }\end{array}$} \\
\hline
\end{tabular}

NE uptake were significantly inhibited within 1 hour of administration (Fig. 3). The inhibitory effects on uptake of both monoamines were dose dependent. The mean values of the half-effective doses $\left(\mathrm{ED}_{50}\right.$ in micromoles/kilogram, Table 3) of LY248686 were slightly lower than that of LY248685 for the inhibition of 5-HT uptake, while the $\mathrm{ED}_{50}$ values of the two isomers for the inhibition of NE uptake were similar (Table 3). LY248686 was approximately five times more potent by the subcutaneous route than by the oral route of administration as an inhibitor of 5-HT and NE uptake ex vivo. Dopamine uptake in striatal homogenates was not affected on administration of either isomer up to 103 $\mu \mathrm{mol} / \mathrm{kg}$ PO (Table 3).

Thus, LY248686 in vitro and in vivo was consistently found to be slightly more potent than its levorotatory isomer, LY248685, in blocking 5-HT uptake in synaptosomal preparations of hypothalamus and cerebral cortex. Moreover, LY248686 was slightly more potent as a $5-\mathrm{HT}$ uptake inhibitor as judged by in vitro $5-\mathrm{HT}$ uptake in human platelets and binding of ${ }^{3} \mathrm{H}$-paroxetine to the 5-HT uptake carrier. Based on these findings, LY248686 was selected over LY248685 for further studies.

Three days after a single administration of p-chloroamphetamine (p-CA) at $10 \mathrm{mg} / \mathrm{kg}$ IP, 5-HT uptake in homogenates of cerebral cortex was significantly reduced to $39 \%$ of control (Table 4). Pretreatment with LY248686 at 26, 52, 92, and $129 \mu \mathrm{mol} / \mathrm{kg}$ IP dose dependently prevented the decrease of 5-HT uptake caused by p-CA treatment. The $\mathrm{ED}_{50}$ of LY248686 was calculated to be $90 \mu \mathrm{mol} / \mathrm{kg}$ IP. The concentrations of $5-\mathrm{HT}$ and its metabolite, 5-HIAA, in hypothalamus were significantly reduced by $\mathrm{p}-\mathrm{CA}$ treatment, which was partially prevented by the highest dose of LY248686 (Table 4).

When LY248686 was administered twice at a dose

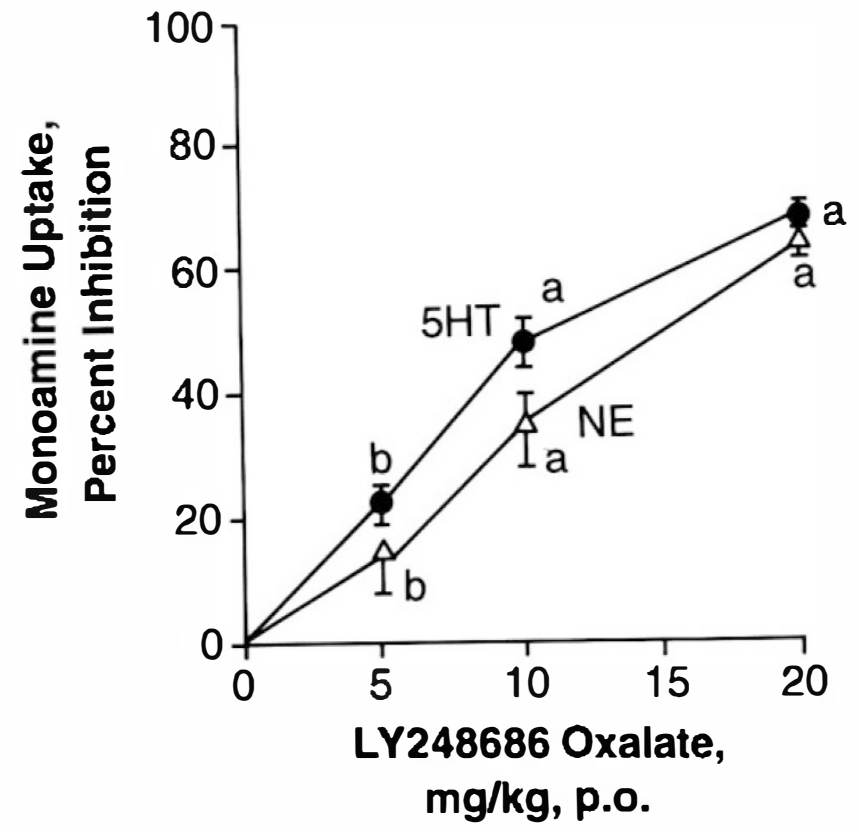

$$
\begin{aligned}
& a, p<0.005 \\
& b, p<0.05
\end{aligned}
$$

Figure 3. Dose-dependent inhibition of 5-HT and NE uptake in rat hypothalamus by LY 248686 ex vivo. Rats (five per group) that had been fasted for 24 hours were treated with 5,10 , or $20 \mathrm{mg} / \mathrm{kg}$ LY248686 oxalate PO one hour before sacrifice. The control group was treated with saline. Aliquots of hypothalamic homogenates were incubated in duplicate samples at $37^{\circ} \mathrm{C}$ for 5 minutes in the same Krebs bicarbonate medium as described in Figure 2, except that both $0.05 \mu \mathrm{mol} / \mathrm{L}$ ${ }^{3} \mathrm{H}-5-\mathrm{HT}$ and $0.1 \mu \mathrm{mol} / \mathrm{L}{ }^{14} \mathrm{C}-\mathrm{NE}$ were included. Accumulation of radioactivity at $4^{\circ} \mathrm{C}$ was subtracted at each dose of uptake inhibitor. Other conditions were as described in Materials and Methods. Significant differences between treated groups and respective control groups are indicated as follows: $a, p<$ $0.005 ; b, p<0.05$. Vertical bars represent $\pm S E$ of the mean percent inhibition. 
Table 3. Reduction of 5-HT and NE Uptake in Hypothalamus and DA Uptake in Striatum Homogenates of Rats Treated with LY248686 and LY248685

\begin{tabular}{|c|c|c|c|}
\hline \multirow[b]{2}{*}{ Uptake Inhibitor } & \multicolumn{3}{|c|}{ Inhibition of Monoamine Uptake } \\
\hline & \multicolumn{3}{|c|}{ (ED 50, micromoles/kilogram) } \\
\hline $\begin{array}{l}\text { LY248686 PO } \\
\text { LY248686 SC }\end{array}$ & $\begin{array}{c}31.2 \pm 4.1 \\
5.2\end{array}$ & $\begin{array}{c}37.7 \pm 5.9 \\
7.7\end{array}$ & $>103$ \\
\hline LY248685 PO & $37.4 \pm 4.1$ & $35.6 \pm 3.6$ & $>103$ \\
\hline
\end{tabular}

Rats (five per group) were treated for one hour with either vehicle or an uptake inhibitor at 5,10 , and $20 \mathrm{mg} / \mathrm{kg}(13,26$, and 52 $\mu \mathrm{mol} / \mathrm{kg}$, respectively) orally in three separate determinations, or at $0.2,0.5,1,5$, and $10 \mathrm{mg} / \mathrm{kg}(0.5,1.3,2.6,13$ and $26 \mu \mathrm{mol} / \mathrm{kg}$, respectively) subcutaneously in one determination. Uptake activities of ${ }^{3} \mathrm{H}-5-\mathrm{HT}$ and ${ }^{14} \mathrm{C}-\mathrm{NE}$ in homogenate of individual hypothalamus in duplicate samples were determined. Uptake of ${ }^{3} \mathrm{H}-\mathrm{DA}$ was determined in striatal homogenates of individual rats treated with LY248686 or LY 248685 at $50 \mathrm{mg} / \mathrm{kg}(103 \mu \mathrm{mol} / \mathrm{kg}) \mathrm{PO}$ an hour before sacrifice. Determinations of uptake of the radioactive monoamines were conducted under conditions as described in Table 2. Value (mean $\pm \mathrm{SE}$ ) was derived from three separate determinations.

of 13,26 , or $52 \mu \mathrm{mol} / \mathrm{kg}$ IP 30 minutes before and 7.5 hours after injection of p-CA, the effects of p-CA on 5 -HT uptake were completely blocked (Table 5). The blockade of the p-CA-induced depletion of 5-HT and 5 -HIAA by the repeated injection of LY248686 at all three doses was partial, but without statistical significance.

Oral administration of LY248686 at 26 and 52 $\mu \mathrm{mol} / \mathrm{kg}$ PO reduced the accumulation of radioactive $\mathrm{NE}$ in rat hearts to $70 \%$ and $37 \%$ of control, respectively, although only the effect at the higher dose was statistically significant (Table 6). Thus, the oral potencies of LY248686 in blocking NE uptake in heart and in brain ex vivo (Table 3 ) are comparable.

\section{Duration of Uptake Inhibition In Vivo}

After a single administration of LY248686 at $52 \mu \mathrm{mol} / \mathrm{kg}$ $P O$, rats were killed at time intervals of $1,3,6$, and 16 hours. The activities of 5-HT and NE uptake in hypothalamic homogenates of the drug-treated groups were significantly reduced 1 to 6 hours after treatment compared with saline-treated control rats (Fig. 4). The ratio of 5-HT and NE uptake inhibition remained constant throughout the 6-hour period. The activities of 5-HT and NE uptake returned to control levels by 16 hours after administration of LY248686.

\section{Food Intake Studies}

As a selective inhibitor of 5-HT uptake, fluoxetine is known to suppress food intake in laboratory animals (Goudie et al. 1976; Wong et al. 1988). In rats deprived of food for 42 hours, LY248686 was as effective as fluoxetine in the suppression of food intake during 1 and 4 hours of food access (Table 7). At twice the dose of LY248686, nisoxetine, a selective inhibitor of NE uptake, suppressed feeding only during the first hour of food access. In a separate experiment, a dosedependent suppression of food intake by LY248686 was demonstrated (Table 7) during both periods of food intake measurement. Coadministration of LY248686 and the 5-HT precursor, 5-hydroxytryptophan (5-HTP), which at a dose of $10 \mathrm{mg} / \mathrm{kg}(45 \mu \mathrm{mol} / \mathrm{kg})$ did not produce significant effects on feeding, produced a more profound suppression of food intake in both periods of measurement. The estimated $E_{50}$ doses of LY248686 during 1 and 4 hours of food access were 13.1 and $36.3 \mu \mathrm{mol} / \mathrm{kg}$, respectively, and were reduced to 4.0 and $10.8 \mu \mathrm{mol} / \mathrm{kg}$, respectively, on combination with 5-HTP.

In radioreceptor assays, LY248686 inhibited ra-

Table 4. Blockade of the Neurotoxicity of p-CA by LY248686: Effect on 5-HT Uptake and Levels of Indoles in Cerebral Cortex

\begin{tabular}{|c|c|c|c|}
\hline \multirow[b]{2}{*}{ Treatment } & \multirow{2}{*}{$\begin{array}{c}\text { 5-HT Uptake } \\
\text { (picomoles/milligram protein) }\end{array}$} & \multicolumn{2}{|c|}{$\begin{array}{c}\text { Levels of Indole } \\
\text { (nanomoles/gram tissue) }\end{array}$} \\
\hline & & 5-HT & 5-HIAA \\
\hline Control & $37.1 \pm 0.1$ & $2.7 \pm 0.0$ & $1.7 \pm 0.1$ \\
\hline $\mathrm{p}-\mathrm{CA}$ & $1.4 \pm 0.1^{\star}$ & $1.4 \pm 0.1^{*}$ & $0.9 \pm 0.0^{*}$ \\
\hline \multicolumn{4}{|l|}{ p-Ca plus LY248686 (micromoles/kilogram) } \\
\hline 26 & $1.7 \pm 0.1^{\star}$ & $1.4 \pm 0.1^{*}$ & $0.9 \pm 0.0^{\star}$ \\
\hline 52 & $2.0 \pm 0.2^{\star t}$ & $1.5 \pm 0.0^{\star}$ & $0.9 \pm 0.0^{\star}$ \\
\hline 90 & $2.6 \pm 0.2^{\star \dagger}$ & $1.7 \pm 0.0^{\star}$ & $1.0 \pm 0.0^{*}$ \\
\hline 129 & $3.4 \pm 0.1^{\dagger}$ & $1.9 \pm 0.9^{\star} \dagger$ & $1.2 \pm 0.1^{\star \dagger}$ \\
\hline
\end{tabular}

Rats (five per group) were treated IP with vehicle or LY248686 at the specified doses a half hour before injection of $10 \mathrm{mg} / \mathrm{kg}$ IP of p-CA. Rats were killed 3 days later and 5-HT uptake in cerebral cortex homogenates and levels of indoles were measured as described in Materials and Methods.

* Significantly different from control group $(p<0.05)$.

+ Significantly different from $\mathrm{p}-\mathrm{CA}$-treated group $(p<0.05)$. 
Table 5. Blockade of the Neurotoxicity of p-Ca by LY248686 Before and After p-CA Treatment: Effect on 5-HT Uptake and Levels of Indoles in Cerebral Cortex

\begin{tabular}{|c|c|c|c|}
\hline \multirow[b]{2}{*}{ Treatment } & \multirow{2}{*}{$\begin{array}{c}\text { 5-HT Uptake } \\
\text { (picomoles/milligram protein) }\end{array}$} & \multicolumn{2}{|c|}{$\begin{array}{c}\text { Levels of Indole } \\
\text { (nanomoles/gram tissue) }\end{array}$} \\
\hline & & 5-HT & 5-HIAA \\
\hline $\begin{array}{l}\text { Control } \\
\text { P-Ca } \\
\text { PCA plus LY248686 (micromoles/kilogram) }\end{array}$ & $\begin{array}{l}3.1 \pm 0.1 \\
1.4 \pm 0.1^{*}\end{array}$ & $\begin{array}{l}5.5 \pm 0.2 \\
3.6 \pm 0.6^{*}\end{array}$ & $\begin{array}{l}2.5 \pm 0.1 \\
1.9 \pm 0.2^{*}\end{array}$ \\
\hline $\begin{array}{l}13 \times 2 \\
26 \times 2 \\
52 \times 2\end{array}$ & $\begin{array}{l}3.7 \pm 0.1^{\dagger} \\
3.5 \pm 0.2^{\dagger} \\
3.8 \pm 0.3^{\dagger}\end{array}$ & $\begin{array}{l}4.1 \pm 0.1^{*} \\
3.8 \pm 0.2^{\dagger} \\
4.4 \pm 0.2^{\dagger}\end{array}$ & $\begin{array}{l}2.4 \pm 0.4 \\
2.0 \pm 0.2 \\
2.3 \pm 0.1\end{array}$ \\
\hline
\end{tabular}

Rats (five per group) were treated IP with vehicle or LY248686 at the specified doses 0.5 hour before and 7.5 hours after injection of $10 \mathrm{mg} / \mathrm{kg} \mathrm{IP} \mathrm{p-CA}$. Rats were killed 3 days later and HT uptake in cortical homogenates and levels of indoles were measured as described in Materials and Methods.

"Significantly different from control group $(p<0.05)$.

+ Significantly different from $\mathrm{p}-\mathrm{CA}$-treated group $(p<0.05)$.

dioligand binding to receptors of neurotransmitters only in micromolar concentrations, including muscarinic acetylcholine receptors, histamine $\mathrm{H}_{1}$ receptors, $\alpha_{1-}, \alpha_{2-}$, and $\beta$-adrenergic receptors, subtypes of $5-\mathrm{HT}_{1}(\mathrm{~A}, \mathrm{~B}$, $C$, and $\mathrm{D}$ ) receptors, $5-\mathrm{HT}_{2}$ receptors, $\mathrm{DA}_{2}$ receptors, and opiate receptors (Table 8).

\section{DISCUSSION}

LY248686 effectively inhibited 5-HT and NE uptake in their respective nerve endings isolated from hypothalamus and cerebral cortex. In these two brain areas, LY248686 is about three times more potent for inhibiting 5-HT uptake than NE uptake. This is consistent with a slightly greater potency of inhibiting ${ }^{3} \mathrm{H}$-paroxetine than ${ }^{3} \mathrm{H}$-tomoxetine binding to uptake carriers of 5-HT (Marcusson et al. 1988) and NE (Wong et al. 1991), respectively. Fluoxetine and nisoxetine, a selective inhibitor of NE uptake (Wong and Bymaster 1976), inhibited ${ }^{3} \mathrm{H}$-paroxetine (Marcusson et al. 1988) and ${ }^{3} \mathrm{H}$ tomoxetine (Wong et al. 1991) binding, respectively, with comparable potencies as those of LY248686. The uptake of 5-HT in human platelets appears to be most

Table 6. Inhibition of Intraveously Injected $\left[{ }^{14} \mathrm{C}\right]-\mathrm{NE}$ Uptake into Rat Heart by Orally Administered LY248686

\begin{tabular}{lc}
\hline $\begin{array}{l}\text { Dose of LY248686 } \\
\text { (micromoles/kilogram PO) }\end{array}$ & $\begin{array}{c}{ }^{14} \text { C-NE Heart Uptake } \\
\text { (dpm/milligram heart) }\end{array}$ \\
\hline Control & $5720 \pm 811$ \\
13 & $7100 \pm 589$ \\
26 & $4054 \pm 291$ \\
52 & $2106 \pm 725^{\star}$ \\
\hline
\end{tabular}

Rats (five per group) were treated orally with saline vehicle or LY248686 at the indicated doses; a half hour later, $1 \mu \mathrm{Ci}$ of ${ }^{14} \mathrm{C}-\mathrm{NE}$ was injected IV. Rats were killed 15 minutes later, and the uptake into heart was determined as described in Materials and Methods.

* Significantly different from control group $(p<0.05)$. sensitive to inhibition by LY248686, having a Ki value of $0.20 \pm 0.04 \mathrm{nmol} / \mathrm{L}$. On the other hand, DA uptake in striatal synaptosomes was less sensitive to inhibition by LY248686, with Ki values 24 and 80 times higher than the Ki values for inhibition of NE and 5-HT uptake, respectively.

Most significantly, oral administration of LY248686 caused concomitant inhibition of 5-HT and NE uptake in a dose-dependent fashion. Subcutaneous administration augments the potencies of LY248686 as an inhibitor of 5-HT and NE uptake six and five times, respectively. However, the greater potency of LY248686 as

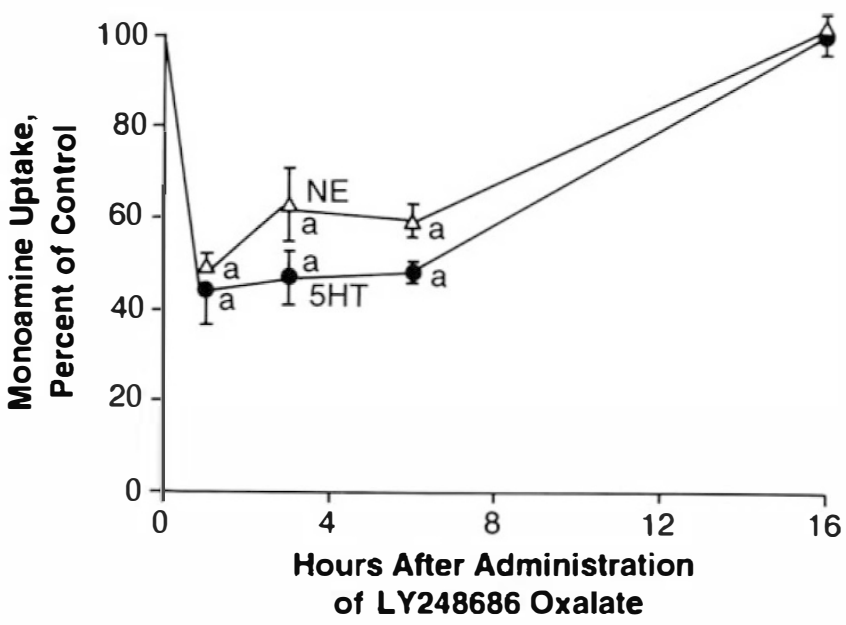

a, $p<0.005$

Figure 4. Duration of inhibition on 5-HT and NE uptake in rat hypothalamus by LY248686 ex vivo. Rats (five per group) that had been fasted 24 hours were treated with $20 \mathrm{mg} / \mathrm{kg}$ PO of LY248686 1, 3, 5, and 16 hours before sacrifice. Control rats received saline. Assays for uptake of ${ }^{3} \mathrm{H}-5-\mathrm{HT}$ and ${ }^{14} \mathrm{C}-$ $\mathrm{NE}$ were as described in Figure 3. Significant differences between the treated and control groups are indicated as follows: a, $p<0.005$. The vertical bars represent $\pm \mathrm{SE}$ of the mean percent of control. 
Table 7. Suppression of Food Intake in Food-Deprived Rats

\begin{tabular}{|c|c|c|c|}
\hline \multirow[b]{2}{*}{ Treatment } & \multirow{2}{*}{$\begin{array}{c}\text { Dose } \\
\text { (millimoles/kilogram) }\end{array}$} & \multicolumn{2}{|c|}{$\begin{array}{l}\text { Cumulative Food Intake } \\
\text { (grams/100 grams } \\
\text { body weight) }\end{array}$} \\
\hline & & 1 Hour & 4 Hours \\
\hline \multicolumn{4}{|l|}{ A } \\
\hline Control & & $1.94 \pm 0.13$ & $3.15 \pm 0.12$ \\
\hline LY248686 & 24.2 & $0.64 \pm 0.10^{\star}$ & $2.48 \pm 0.14^{\dagger}$ \\
\hline Fluoxetine & 28.9 & $0.73 \pm 0.01^{\star}$ & $2.02 \pm 0.12^{\star}$ \\
\hline Nisoxetine & 65.0 & $0.95 \pm 0.21^{\star}$ & $2.50 \pm 0.34$ \\
\hline \multicolumn{4}{|l|}{ B } \\
\hline Control & & $1.20 \pm 0.09$ & $2.81 \pm 0.00$ \\
\hline \multirow[t]{3}{*}{ LY248686 } & 7.7 & $0.82 \pm 0.25$ & $2.60 \pm 0.15$ \\
\hline & 13.1 & $0.62 \pm 0.03^{\dagger}$ & $2.20 \pm 0.04^{*}$ \\
\hline & 25.9 & $0.26 \pm 0.06^{\star}$ & $1.66 \pm 0.12^{*}$ \\
\hline \multirow[t]{4}{*}{ 5-HTP plus LY248686 } & 45.0 & $0.80 \pm 0.05$ & $2.80 \pm 0.11$ \\
\hline & 7.7 & $0.42 \pm 0.06^{\dagger}$ & $1.72 \pm 0.05$ \\
\hline & 13.1 & $0.29 \pm 0.18 \ddagger$ & $1.36 \pm 0.24$ \\
\hline & 25.9 & $0.01 \pm 0.01^{\star}$ & $0.32 \pm 0.14^{\star}$ \\
\hline
\end{tabular}

Rats (six in Group A and three in Group B) deprived of food for $\mathbf{4 2}$ hours were treated with saline, LY248686, fluoxetine, nisoxetine or 5-hydroxytryptophan (5-HTP) at the specified dose a half hour before food access.

Statistically significant differences between saline and drug-treated groups: ${ }^{\star} p<0.001 ;{ }^{\dagger} p<0.005$; $\ddagger p<0.025$.

an inhibitor of 5-HT uptake than NE uptake in vitro are not translated into in vivo differences, as indicated by the similar $\mathrm{ED}_{50}$ values.

p-Chloroamphetamine and 6-OHDA appear to use the uptake carriers of 5-HT and NE, respectively, to enter the corresponding nerve terminals before initiation of depletion of the monoamines and decreases of uptake activities due to neurotoxicity (Evetts and Iversen 1970; Meek et al. 1971; Fuller and Wong 1977). Fluoxetine, a selective inhibitor of 5-HT uptake, blocks only the p-CA-induced depletion of 5-HT, with an $\mathrm{ED}_{50}$ of $1.2 \mu \mathrm{mol} / \mathrm{kg} \mathrm{IP}$ (Fuller and Wong, 1987), while tomoxetine, a selective inhibitor of NE uptake, blocks only the 6-OHDA-induced depletion of NE in heart with an $\mathrm{ED}_{50}$ of $5.8 \mu \mathrm{mol} / \mathrm{kg}$ IP (Fuller and Wong 1987). In this

Table 8. Affinity of LY248686 for Neuronal Receptors

\begin{tabular}{|c|c|}
\hline Measurement & $\begin{array}{c}\text { Ly248686 } \\
\left(\mathrm{IC} \mathrm{C0}_{50} \mathrm{nmol} / \mathrm{L}\right)\end{array}$ \\
\hline $\begin{array}{l}{ }^{3} \mathrm{H}-\mathrm{QNB} \text { binding ( } \mathrm{ACh} \text { receptor) } \\
{ }^{3} \mathrm{H} \text {-Pyrilamine binding }\end{array}$ & 3,000 \\
\hline (histamine- 1 receptor) & 2,300 \\
\hline $\begin{array}{l}{ }^{3} \mathrm{H}-\mathrm{WB} 4101 \text { binding ( } \alpha 1 \text {-adrenergic } \\
\text { receptor) }\end{array}$ & 8,300 \\
\hline${ }^{3} \mathrm{H}-8-\mathrm{OH}-\mathrm{DPAT}$ (5- $\mathrm{HT}_{1 \mathrm{~A}}$ receptor) & 2,750 \\
\hline${ }^{3} \mathrm{H}-5-\mathrm{HT}$ binding (5-HT ${ }_{1 \mathrm{~B}}$ receptor) & 710 \\
\hline${ }^{3} \mathrm{H}-$ Mesulergine binding (5- $\mathrm{HT}_{1 \mathrm{C}}$ receptor) & $>1,000$ \\
\hline${ }^{3} \mathrm{H}-5-\mathrm{HT}$ binding (5-HT $1 \mathrm{D}$ receptor) & 1,725 \\
\hline${ }^{3} \mathrm{H}-$ Ketanserin binding (5- $\mathrm{HT}_{2}$ receptor) & $>1,000$ \\
\hline${ }^{3} \mathrm{H}-$ Spiperone ( $D_{-2}$ dopamine receptor) & 14,000 \\
\hline${ }^{3} \mathrm{H}-\mathrm{Nal}$ oxone (opiate receptor) & 18,000 \\
\hline
\end{tabular}

study LY248686 also prevents the decrease of brain 5-HT uptake caused by treatment with p-CA, with an $\mathrm{ED}_{50}$ dose of $90 \mu \mathrm{mol} / \mathrm{kg}$ IP; LY248686 lowers uptake of NE in heart in vivo and in hypothalamic homogenate ex vivo with comparable potencies. In previous studies, amitriptyline at $159 \mu \mathrm{mol} / \mathrm{kg}$ IP gave only $32 \%$ protection from the decrease of 5-HT uptake caused by $\mathrm{p}-\mathrm{CA}$ treatment and $50 \%$ protection from the decrease of $\mathrm{NE}$ uptake caused by 6-hydroxydopamine treatment (Wong and Bymaster 1976). The apparent lower potencies of LY248686 and amitriptyline as antagonists of the p-CA-induced decrease of 5-HT uptake is probably due to the shorter durations of action of these uptake inhibitors than that of p-CA (Fuller et al. 1977). Indeed, antagonism of the p-CA-induced decreases of 5-HT uptake was rendered more complete by administering half of the dose of LY248686 twice, i.e., 30 minutes before and 7.5 hours after p-CA treatment. The $\mathrm{ED}_{50}$ was reduced from 90 to less than $13 \times 2 \mu \mathrm{mol} / \mathrm{kg}$ IP (Tables 4 and 5), a dose intermediate between the $\mathrm{ED}_{50}$ determined by subcutaneous and oral routes of administration (Table 3).

Moreover, the concomitant inhibition of 5-HT and NE uptake by LY248686 after a single administration persists for as long as 6 hours, which is comparable to the duration of lowering NE uptake by tomoxetine ex vivo (Wong et al. 1982) but shorter than the duration of 24-hour inhibition of 5-HT uptake by fluoxetine (Wong et al. 1975). Amitriptyline, however, after a single administration of $20 \mathrm{mg} / \mathrm{kg} \mathrm{SC}$, failed to lower $5-\mathrm{HT}$ uptake, but did lower NE uptake within 1 and 6 hours 
to $35 \%$ and $48 \%$ of the control activities, respectively (data not shown).

LY248686 at doses that blocked uptake of 5-HT and $\mathrm{NE}$ ex vivo effectively suppressed feeding of fooddeprived rats. The synergistic effect of 5-HTP, a precursor amino acid of 5-HT, supports the notion that the anorectic effects depend on synaptic supply of 5-HT, which as a neurotransmitter exerts an inhibitory role on feeding behavior (Blundell 1977; Wong and Fuller 1987). The present studies show that LY248686 treatment up to 4 hours (Table 7) is at least as effective as fluoxetine, which has been demonstrated to suppress food intake of various feeding paradigms in normal and genetically obese rodents (Wong et al. 1988; Fuller and Wong, 1989). In a similar feeding paradigm, amitriptyline or imipramine at doses up to $10 \mathrm{mg} / \mathrm{kg}(32 \mu \mathrm{mol} / \mathrm{kg})$ IP failed to suppress food intake in rats after food deprivation (data not shown). On the other hand, concomitant inhibition of NE uptake has not negated the appetite-suppressive effects of LY248686, although $a$-adrenergic stimulation is known to increase feeding (Weiss et al. 1986). Moreover, as a potential antidepressant drug, LY248686 would be anticipated to have a low propensity to cause weight gain.

In addition, animal studies show that LY248686 produced other pharmacological responses consistent with its action as an inhibitor of 5-HT and NE uptake (Fuller and Wong 1977; Wong et al. 1985, 1988, 1990). At doses effectively inhibiting 5-HT uptake in vivo, LY248686 lowers alcohol intake in high-alcohol-drinking rats (Murphy et al. 1989), potentiates the analgesic effects of morphine in mouse writhing tests (J.D. Leander, personal communication; Hynes and Fuller 1982), and potentiates the tremor and head twitch induced by 5-HTP (J.D. Leander, personal communication; Hwang and VanWoert 1980). Thus, the ability of LY248686 to inhibit NE uptake does not have a negative influence on its ability to promote serotonergic functions. Because of the weak affinity for subtypes of 5-HT receptors, the pharmacological responses are not likely to be mediated by direct interaction between the uptake inhibitor and the 5-HT receptors examined. On the other hand, as demonstrated with other inhibitors of NE uptake, LY248686 blocks the hypothermic effects of apomorphine(J.D. Leander, personal communication; Menon etal. 1984), and potentiates the analgesic effect of clonidine in the mouse writhing tests (J.D. Leander, personal communication; Hynes and Henderson 1984).

Down-regulation of $\beta$-adrenergic receptors after long-term administration of tricyclic antidepressant drugs (Frazer et al. 1974; Banerjee et al. 1977) and electroconvulsive shock (Bergstrom and Kellar, 1977) may depend not only on the input from NE neurons (Wolfe et al. 1978), but also on 5-HT innervation (Brunello et al. 1982; Janowsky et al. 1982). Since selective lesions of 5-HT terminals with 5,7-dihydroxytryptamine, but not merely inhibition of 5 -HT synthesis by p-chlorophenylalanine, prevent down-regulation of $\beta$-adrenergic receptors by antidepressant treatments, a factor present in 5-HT terminals other than 5-HT itself may be involved (Nimgaonkar et al. 1985). The combined chronic administration of desipramine and fluoxetine appears to produce a rapid down-regulation of rat cortical $\beta$-adrenergic receptors (Dudley and Baron 1989). Thus, there appear to be cooperative interactions between the NE and 5-HT neurotransmission systems. A persistent inhibitor of 5-HT and NE uptake such as LY248686 might facilitate the adaptive changes in $\beta$-adrenergic receptors as a consequence of a concerted augmentation of the 5- $\mathrm{HT}$ and NE neurotransmission systems.

The transporters of 5-HT and NE have been useful biochemical and pharmacological targets for the development of antidepressant drugs. Fluoxetine, a selective inhibitor of 5-HT uptake, has ample evidence for its antidepressive efficacy (Benfield et al. 1986; Beasley et al. 1990), while tomoxetine, a selective inhibitor of NE uptake, might also have antidepressant effects (Chouinard et al. 1984). Other selective inhibitors of 5-HT uptake, including citalopram (Dufour et al. 1987), indalpine (Shopsin et al. 1983) and sertraline (Doogan and Caillard 1988), also possess antidepressive efficacy. LY248686, a member of the naphthalenyloxythiophenepropanamine series, being endowed with the ability to inhibit the uptake of 5-HT and NE concomitantly, may have therapeutic potential in the treatment of depression. Indeed, a preliminary study of the combination of fluoxetine and desipramine suggests a more rapid onset of antidepressant effect (Nelson et al. 1991).

The tricyclic antidepressant drugs (Wernicke et al. 1987) appear to produce side effects by antagonizing the central as well as peripheral muscarinic-acetylcholine receptors, histamine-H1 receptors, and $\alpha$-adrenergic receptors (Richelson and Nelson 1984). Because of their low affinity for these neuronal receptors, fluoxetine and its congeners tend to produce fewer side effects (Wernicke et al. 1987). With relatively weak affinity for the neuronal receptors examined, LY248686 might have a lower propensity to produce a profile of side effects generally associated with the tricyclic antidepressant drugs. Moreover, because of its ability to suppress food intake, LY248686 may have a low propensity to stimulate weight gain during treatment of depression.

In summary, we have described the biochemical pharmacology of LY248686, a potent inhibitor of 5-HT and NE uptake. LY248686 may be a useful pharmacological tool to determine if the simultaneous facilitation of 5-HT and NE neurotransmission provides advantages relative to compounds that affect only one of these 
neurotransmitter systems. Moreover, LY248686 exhibits the pharmacological profile of a potential antidepressant drug.

\section{ACKNOWLEDGMENTS}

We thankRichard D. Marsh and Penny G. Threlkeld, for technical assistance and Joan Hager for secretarial assistance.

\section{REFERENCES}

Banerjee SP, Kung LS, Riggi SJ, Chande SK (1977): Development of $\beta$-adrenergic receptor subsensitivity by antidepressants. Nature (Lond) 268:455-456

Beasley CM Jr, Bosomworth JC, Wernicke JF (1990): Fluoxetine: Relationships among doseresponse, adverse events, and plasma concentrations in the treatment of depression. Psychopharmacol Bull 26:18-24

Benfield P, Heel RC, Lewis SP (1986): Fluoxetine: A review of its pharmacodynamic and pharmacokinetic properties, and therapeutic efficacy in depressive illness. Drugs 32:481-508

Bergstrom DA, Kellar KJ (1977): Effect of electroconvulsive shock on monoaminergic receptor subsensitivity by antidepressants. Nature (Lond) 268:455-456

Blundell JE (1977): Is there a role for serotonin (5-hydroxytryptamine) in feeding? Int J Obes 1:15-42

BrunelloN, Barbaccia ML, ChuangDM, CostaE (1982): Downregulation of beta-adrenergic receptors following repeated desipramine injections: permissive role of serotonergic axons. Neuropharmacology 21:1145-1149

Cheng YC, Prusoff WH (1973): Relationship between the inhibition constant $(\mathrm{Ki})$ and the concentrations of inhibitor which causes 50 percent inhibition $\left(\mathrm{IC}_{50}\right.$ ) of an enzymatic reaction. Biochem Pharmacol 22:3099-3108

Chouinard G, Annable L, Bradweijn J (1984): An early phase II clinical trial of tomoxetine (LY139603) in the treatment of newly admitted depressed patients. Psychopharmacology 83:126-128

Corona GL, Cucchi ML, Frattini P, Santagostino G, Schinelli S, Zerbi F, Savoldi F (1990): Aspects of amitriptyline and nortriptyline plasma levels monitoring in depression. Psychopharmacology (Berlin) 100:334-338

Doods HN, Kalkman HO, DeJonge A, Toolen MJMC, Wilffert B, Timmermans PB, Van Zwieten PA (1985): Differential selectivities of RU24969 and 8-OH-DPAT for the purported 5- $\mathrm{HT}_{1 \mathrm{~A}}$ and $5-\mathrm{HT}_{1 \mathrm{~B}}$ binding sites correlation between $5 \mathrm{HT}_{1 \mathrm{~A}}$ affinity and hypotensive activity. Eur J Pharmacol 112:363-370

Doogan DP, Caillard V (1988): Sertraline: A new antidepressant. J Clin Psychiatry 49(suppl):46-51

Dudley M, Baron B (1989): The role of the $5 \mathrm{HT}_{1 \mathrm{~A}}$ receptor in the rapid down-regulation of rat cortical $\beta$-adrenoceptors produced by co-administration of desipramine and fluoxetine. Abstracts, International Symposium on Serotonin from Cell Biology to Pharmacology and Therapeutics. City, Publisher, p 88 Florence Italy

Dufour H, Bouchacourt M, Thermoz P, Viala A, Rop PP,
Gouezo F, Durand A, Petersen HEH (1987): Citalopram - a highly selective 5HT uptake inhibitor in the treatment of depressed patients. Int Clin Psychopharmacol 2:225-237

Evetts KD, Iversen LL (1970): Effects of protryptyline on the depletion of catecholamines induced by 6-hydroxydopamine in the brain of the rat. J Pharm Pharmacol 22:540-542

Frazer A, Pandey G, Mendels J (1974): The effect of trisiodothyronine in combination with imipramine on $\left[{ }^{3} \mathrm{H}\right]$ cyclic AMP production in slides of rat cerebral cortex. Neuropharmacology 13:1131-1140

Fuller RW, Wong DT (1977): Inhibition of serotonin reuptake. Fed Proc 36:2154-2158

Fuller RW, Wong DT (1987): Serotonin reuptake blockers in vitro and in vivo. J Clin Psychopharmacol 7:36S-43S

Fuller RW, Wong DT (1989): Fluoxetine: A serotonergic appetite suppression drug. Drug Dev Res 17:1-15

Fuller RW, Snoddy HD, Perry KW, Bymaster FP, Wong DT (1977): Importance of duration of drug action in the antagonism of p-chloroamphetamine depletion of brain serotonin-comparison of fluoxetine and chlorimipramine. Biochem Pharmacol 27:193-198

Goudie AJ, Thornton EW, Sheeler TJ (1976): Effect of Lilly 110140 , a selective inhibitor of 5-hydroxytryptamine uptake, on food intake and on 5-hydroxytryptophan-induced anorexia: Evidence for serotonergic inhibition of feeding. J Pharm Pharmacol 28:318-320

Gozlan H, Mestikawy SE, Pichat L, Glowinski J, Hamon M (1983): Identification of presynaptic serotonin autoreceptors using a new ligand: ${ }^{3} \mathrm{H}-\mathrm{PAT}$. Nature (Lond) 305:140-142

Hertting G, Axelrod J, Whitby LG (1961): Effect of drugs on the uptake and metabolism of $\left[{ }^{3} \mathrm{H}\right]$ norepinephrine. J Pharmacol Exp Ther 134:146-153

Heuring RE, Peroutka SJ (1987): Characterization of a novel ${ }^{3} \mathrm{H}-5$-hydroxytryptamine binding site subtype in bovine brain membranes. J Neurosci 7:894-903

Horng JS, Wong DT (1976): Effects of serotonin uptake inhibitor, Lilly 110140, on transport of serotonin in rat and human blood platelets. Biochem Pharmacol 25:865-867

Hoyer D, Engel G, Kalkman HO (1985): Molecular pharmacology of $5-\mathrm{HT}_{1}$ and $5-\mathrm{HT}_{2}$ recognition sites in rat and pig brain membranes: Radioligand binding studies with $\left[{ }^{3} \mathrm{H}\right] 5-\mathrm{HT},\left[{ }^{3} \mathrm{H}\right] 8-\mathrm{OH}-\mathrm{DPAT},(-)\left[{ }^{125}\right]$ iodocyanopindolol, $\left[{ }^{3} \mathrm{H}\right]$ mesulergine and $\left[{ }^{3} \mathrm{H}\right]$ ketanserin. Eur J Pharmacol 118:13-23

HwangEC, VanWoert MH(1980): Acuteversus chronic effects of serotonin uptake blockers on potentiation of the "serotonin syndrome." Commun Psychopharmacol 4: 161-167

Hynes MD, Fuller RW (1982): The effect of fluoxetine on morphine analgesia, respiratory depression, and lethality. Drug Dev Res 2:33-42

Hynes MD, Henderson JK (1984): Modification of alphaadrenoceptor agonist antinociceptive activity by nisoxetine: A selective inhibitor of noradrenergic uptake. Pharmacol Biochem Behav 20:463-466

Janowsky A, Okada F, Manier DH, Applegate C, Sulser F (1982): Role of serotonergic input in the regulation of the beta-adrenergic receptor-coupled adenylate cyclase system. Science (Wash DC) 218:900-901 
Leysen JE, Niemegeers CJE, Nueten JM, Laduron PM (1982): $\left[{ }^{3} \mathrm{H}\right]$ Ketanserin (R41468), a selective ${ }^{3} \mathrm{H}$ ligand for serotonin2 receptor binding sites. Mol Pharmacol 21:301-314

Marcusson JO, Bergstrom M, Eriksson K, Ross SB (1988): Characterization of $\left[{ }^{3} \mathrm{H}\right]$ paroxetine binding in rat brain. J Neurochem 50:1783-1790

Meek J, Fuxe K, Carlsson A (1971): Blockade of p-chloroamphetamine induced 5-hydroxytryptamine depletion by chlorimipramine, chlorpheniramine and meperidine. Biochem Pharmacol 20:707-709

Menon MK, Vivonia CA, King AS (1984): Pharmacological studies on the antagonism by antidepressants of the hypothermia induced by apomorphine. Neuropharmacology 322a:121-127

Murphy JM, McBride WJ, Lumeng L, Li T-K, Wong DT (1989): Suppression of alcohol and food intake by LY264453, a new inhibitor of serotonin (5-HT) and norepinephrine (NE) uptake. Abs Soc Neurosci 15:58

Muscettola G, Goodwin FK, Potter WZ, Clacys MM, Markey SP (1978): Imipramine and desipramine in plasma and spinal fluid. Arch Gen Psychiatry 35:621-625

Narasimhachari N, Landa B (1991): Incidence of high and low hydroxylator and demethylator phenotypes in patients on antidepressant therapy. Clin Pharmacol Ther Abs 49:P1-51, 136

Nelson JC, Mazure CM, Bowers MB, Jatlow Pl (1991): A preliminary, open study of the combination of fluoxetine and desipramine for rapid treatment of major depression. Arch Gen Psychiatry 48 303-307

Nimgaonkar VL, Goodwin GM, Davies CL, Green AR (1985): Down-regulation of $\beta$-adrenoceptors in rat cortex by repeated administration of desipramine, electroconvulsive shock and clenbuterol requires $5 \mathrm{HT}$ neurones but not 5HT. Neuropharmacology 24:279-283

Richelson E (1987): Pharmacology of antidepressants. Psychopathology 20(suppl 1):1-12

Richelson E, Nelson A (1984): Antagonism by antidepressants of neurotransmitter receptors of normal brain in vitro. J Pharmacol Exp Ther 230:94-102

Shopsin B, Lefebvre C, Maulet C (1983): Indalpine (LM5008): An open study in depressed outpatients. Curr Therapeutic Res 34:239-252

Weiss GF, Papadakos P, Knudson K, Leibowitz SF (1986): Medial hypothalamic serotonin: Effects on deprivation and norepinephrine-induced eating. Pharmacol Biochem Behav 25:1223-1230
Wernicke JF, Dunlop SF, Dornseif BE, Zerbe RL (1987): Fixed dose fluoxetine therapy for depression. Psychopharmacol Bull 23:164-168

Wolfe BB, Harden TK, Sporn JF, Molinoff PB (1978): Presynaptic modulation of beta-adrenergic receptors in rat cerebral cortex after treatment with antidepressant. J Pharmacol Exp Ther 207:446-457

Wong DT, Bymaster FP (1976): The comparison of fluoxetine and nisoxetine with tricyclic antidepressants in blocking the neurotoxicity of p-chloroamphetamine and 6-hydroxydopamine in the rat brain. Res Commun Chem Pathol Pharmacol 15:221-231

Wong DT, Fuller RW (1987): Serotonergic mechanisms in feeding. Int J Obes 11(suppl 3):125-133

Wong DT, Horng JS, Bymaster FP, Hauser KL, Molloy BB (1974): A selective inhibitor of serotonin uptake: Lilly 110140, 3-(p-trifluoromethylphenoxy)-N-methyl-3phenylpropylamine. Life Sci 15:471-479

Wong DT, Bymaster FP, Horng JS, Molloy BB (1975): A new selective inhibitor for uptake of serotonin into synaptosomes of rat brain 3-(p-trifluoromethylphenoxy)-Nmethyl-3-phenylpropylamine. J Pharmacol Exp Ther 193:804-811

Wong DT, Threlkeld PG, Best KL, Bymaster FP(1982): A new inhibitor of norepinephrine uptake devoid of affinity for receptors of rat brain. J Pharmacol Exp Ther 222:61-65

Wong DT, Bymaster FP, Reid LR, Threlkeld PG (1983): Fluoxetine and two other serotonin uptake inhibitors without affinity for neuronal receptors. Biochem Pharmacol 32:1287-1293

Wong DT, Bymaster FP, Reid LR, Fuller RW, Perry KW (1985): Inhibition of serotonin uptake by optical isomers of fluoxetine. Drug Dev Res 6:397-403

Wong DT, Reid LR, Threlkeld PG (1988): Suppression of food intake in rats by fluoxetine: Comparison of enantiomers and effects of serotonin antagonists. Pharmacol Biochem Behav 31:475-479

Wong DT, Fuller RW, Robertson DW (1990): Fluoxetine and its two enantiomers as selective serotonin uptake inhibitors. Acta Pharm Nord 2:171-180

Wong DT, Robertson DW, Gackenheimer SL, Reid L, Schober DA, Thompson DC, Gehlert DR (1991): [ $\left.{ }^{3} \mathrm{H}\right]$-Tomoxetine: a highly selective, enantiomerically pure radioligand for norepinephrine uptake sites in brain. Abstr Soc Neurosci 17:90 